\title{
Do Birth Season and Sex Affect Adult Lung Function as Early Life Factors?
}

\author{
Tae Beom Kim1, I-Nae Park ${ }^{2 *}$ \\ ${ }^{1}$ Department of Urology, Gachon University Gil Hospital, Incheon, Republic of Korea \\ ${ }^{2}$ Department of Pulmonology, Inje University Seoul Paik Hospital, Seoul, Republic of Korea \\ Email: *eanee@hanmail.net
}

How to cite this paper: Kim, T.B. and Park, I-N. (2017) Do Birth Season and Sex Affect Adult Lung Function as Early Life Factors? Health, 9, 223-236.

https://doi.org/10.4236/health.2017.92015

Received: December 5, 2016

Accepted: February 4, 2017

Published: February 7, 2017

Copyright $\odot 2017$ by authors and Scientific Research Publishing Inc. This work is licensed under the Creative Commons Attribution-NonCommercial International License (CC BY-NC 4.0). http://creativecommons.org/licenses/by-nc/4.0/ cC) (1) (8) Open Access

\begin{abstract}
Objectives: Although lung function decline is a normal ageing process, it can be potentiated by risk factors. However, the potential impact of early life factors on lung function decline has been scarcely studied. The aim of this study was to investigate the potential correlation between birth season and adult lung function. Methods: We enrolled 1008 South Korean patients (530 men and 478 women; age range, 40 - 80 years) who were hospitalized for urological surgery, irrespective of respiratory disease. All patients underwent the pulmonary function test before any surgery or procedure. Based on their birth season, the patients were divided into two groups (spring, summer, and fall vs. winter). Results: Forced vital capacity (FVC), forced expiratory volume in 1 second (FEV1), and FEV1 \% predicted of men born in winter were lower than those of men born in other seasons. Univariate and multivariate analyses using linear regression models also showed that birth season was a significant predictive factor for FVC, FEV1, and FEV1 \% predicted in men. However, birth season was not correlated with lung function in women. Among male ever-smokers, FEV1 and FEV1 \% predicted were lower for men born in winter than for those born in other seasons. Conclusions: Unlike women, men born in winter had lower lung function than did men born in other seasons. These results suggest that birth season might be an early life factor that predicts airway function. Furthermore, birth season has different effects on adult lung function depending on the patient's sex.
\end{abstract}

\section{Keywords}

Birth Season, Early Life Factor, Sex, Lung Function

\section{Introduction}

Chronic obstructive pulmonary disease (COPD) is set to become the third most important cause of death worldwide [1]. It is an umbrella term for a spectrum of 
diseases characterized by an airflow limitation that is not fully reversible. Although tobacco smoking is known to be the major risk factor for COPD and the main determinant of a poor outcome in patients with COPD [2] [3], 5\% - 10\% of non-smoking young adults and up to $30 \%$ of non-smoking adults aged 60 years or more have symptoms of COPD [4]. Also only a portion of smokers develop COPD, suggesting that an individual smoker's susceptibility to COPD is determined by the interaction between environmental factors (tobacco smoke or air pollutants) and host factors (genetics, early lung growth, race, or sex) [4] [5] [6].

An increasing body of evidence suggests that COPD is not simply a disease of old age that is largely restricted to heavy smokers, but may be associated with insults to the developing lung during fetal life and the first few years of postnatal life, when lung growth and development are rapid [7] [8]. Recently, two European multi-center cohort studies, namely, the Swiss Study on Air Pollution and Lung Disease in Adults (SAPALDIA) and the European Community Respiratory Health Survey (ECRHS) [9], showed that early life factors predicted lung function decline in old age, suggesting that lung ageing is programmed early in life. One of the novel findings of these studies was the association of lung function decline with birth season. Participants born in winter months had a more rapid decline in lung function than did those born in other months.

To date, the potential impact of birth season as an early life factors on lung function has been scarcely studied. The aim of this study was to investigate the potential correlation between birth season (month of birth) and adult lung function.

\section{Methods}

\subsection{Patient Selection}

The study was approved by the Gachon University Gil Hospital Institutional Review Board (GCIRB2016-107). A total of 1008 South Korean patients (530 men and 478 women; age range, 40 - 80 years) who were hospitalized for urological surgery at a single tertiary academic center were enrolled in our investigation irrespective of respiratory disease. Based on the smoking histories, "neversmokers" were defined as those who had smoked on average $<1$ cigarette/day for $<6$ months or had never smoked. For the "ever-smokers", pack-years were calculated to quantify tobacco use, with 1 pack-year being equivalent to smoking an average of 20 cigarettes/day for 1 year.

\subsection{Pulmonary Function Tests (PFTs)}

All 1008 patients underwent spirometry before undergoing any operation or procedure. The tests were performed according to the American Thoracic Society guidelines [10] [11]. Spirometry indices included the forced vital capacity (FVC), forced expiratory volume in 1 second (FEV1), and FEV1/FVC ratio. The predicted values, FVC \% predicted and FEV1\% predicted, were calculated using formulas that take into account the race, sex, age, height, and weight of a person. We did not measure post-bronchodilator responses. 


\subsection{Birth Season}

We recorded the patients' birth seasons based on their birth months as follows: spring (March-May), summer (June-August), fall (September-November), and winter (December-February, mean temperature of January in Korea: $-6^{\circ} \mathrm{C}$ $3^{\circ} \mathrm{C}$ ). Comparisons were performed between patients born in winter and those born in other seasons.

\subsection{Statistical Analysis}

The relationships between the study variables were analyzed using Pearson's linear correlation. To identify the independent predictive factors influencing lung function, we performed univariate and multivariate analyses using linear regression modeling. Student's $t$-test was used to compare variables between the two study groups according to birth seasons (i.e., spring, summer, and fall vs. winter) and sex. All analyses were performed using SPSS 12.0 (SPSS Inc., Chicago, IL, USA) and $\mathrm{p}<0.05$ was considered statistically significant.

\section{Results}

\subsection{Patient Characteristics}

Characteristics of all 1008 patients are summarized in Table 1. Of the PFT findings, FVC and FEV1 were higher in men than in women (Table 1). The FEV1/FVC ratio and FEV1 \% predicted were lower in men than in women (Table 1).

Table 1. Characteristics of the study population.

\begin{tabular}{cccc}
\hline & Men $(\mathrm{N}=530)$ & Women $(\mathrm{N}=478)$ & p-value \\
\cline { 2 - 3 } & Mean \pm SD & Mean \pm SD & \\
\hline Age (years) & $68.4 \pm 7.0$ & $67.6 \pm 7.2$ & 0.08 \\
Height (cm) & $166.8 \pm 5.9$ & $153.6 \pm 6.0$ & $<0.05$ \\
Weight (kg) & $65.6 \pm 9.0$ & $58.6 \pm 9.2$ & $<0.05$ \\
BMI (kg/m $)$ & $23.5 \pm 2.7$ & $24.8 \pm 3.6$ & $<0.05$ \\
FVC (L) & $3.60 \pm 0.68$ & $2.48 \pm 0.46$ & $<0.05$ \\
FEV1 (L) & $2.60 \pm 0.63$ & $1.96 \pm 0.40$ & $<0.05$ \\
FEV1/FVC (\%) & $71.9 \pm 10.3$ & $78.9 \pm 6.8$ & $<0.05$ \\
predFVC (\%) & $95.6 \pm 16.3$ & $94.1 \pm 17.1$ & 0.15 \\
predFEV1 (\%) & $99.8 \pm 22.1$ & $102.6 \pm 22.5$ & 0.05 \\
Smoking (PY) & $14.4 \pm 20.8$ & $0.6 \pm 4.0$ & $<0.05$ \\
Smoker (\%) & $46.4 \%(246 / 530)$ & $3.1 \%(15 / 478)$ & $<0.05$ \\
Smoking of smoker (PY) & $32.7 \pm 19.6$ & $19.0 \pm 12.8$ & $<0.05$ \\
FEV1/FVC < 70 (\%) & $32.6 \%(173 / 530)$ & $7.3 \%(35 / 478)$ & $<0.05$ \\
\hline
\end{tabular}

Abbreviations: BMI, Body mass index; FVC, Forced vital capacity; FEV1, Forced expiratory volume in 1 second; predFVC, FVC \% predicted; predFEV1, FEV1 \% predicted; PY, pack-years. 


\subsection{Comparison between Birth Seasons (Spring, Summer, and Fall vs. Winter)}

FEV1 \% predicted of men born in winter was lower than that of women born in winter $(96.3 \pm 21.9$ vs. $104.3 \pm 20.1, \mathrm{p}<0.05)$ (Figure 1). However, there were no differences in FEV1 \% predicted between men and women born in spring, summer, and fall (Figure 1).

FVC, FEV1, and FEV1 \% predicted of men born in winter were lower than those of men born in other seasons (Table 2). However, no differences in PFT findings were observed between women in the two groups based on birth season (spring, summer, and fall vs. winter) (Table 2).

\subsection{Correlation Study}

Univariate analysis using linear regression models showed that birth season was a significant predictive factor for FVC, FEV1, and FEV1 \% predicted in men (FVC: $\mathrm{r}=0.090, \mathrm{p}<0.05$; FEV1: $\mathrm{r}=0.104, \mathrm{p}<0.05$; FEV1 \% predicted: $\mathrm{r}=$ $0.105, \mathrm{p}<0.05)$ (Table 3). Furthermore, multivariate analysis using linear regression models showed that birth season was still a significant factor for predicting lung function in men (FVC: $\beta=0.080, \mathrm{p}<0.05$; FEV1: $\beta=0.094, \mathrm{p}<$ 0.05 ; FEV1 \% predicted: $\beta=0.103, \mathrm{p}<0.05$ ) (Table 4). In contrast, birth season was not correlated with lung function in women (Table 3 and Table 4).

\subsection{Smoking}

Out of the 530 men, 246 (46.4\%) were ever-smokers; mean smoking exposures

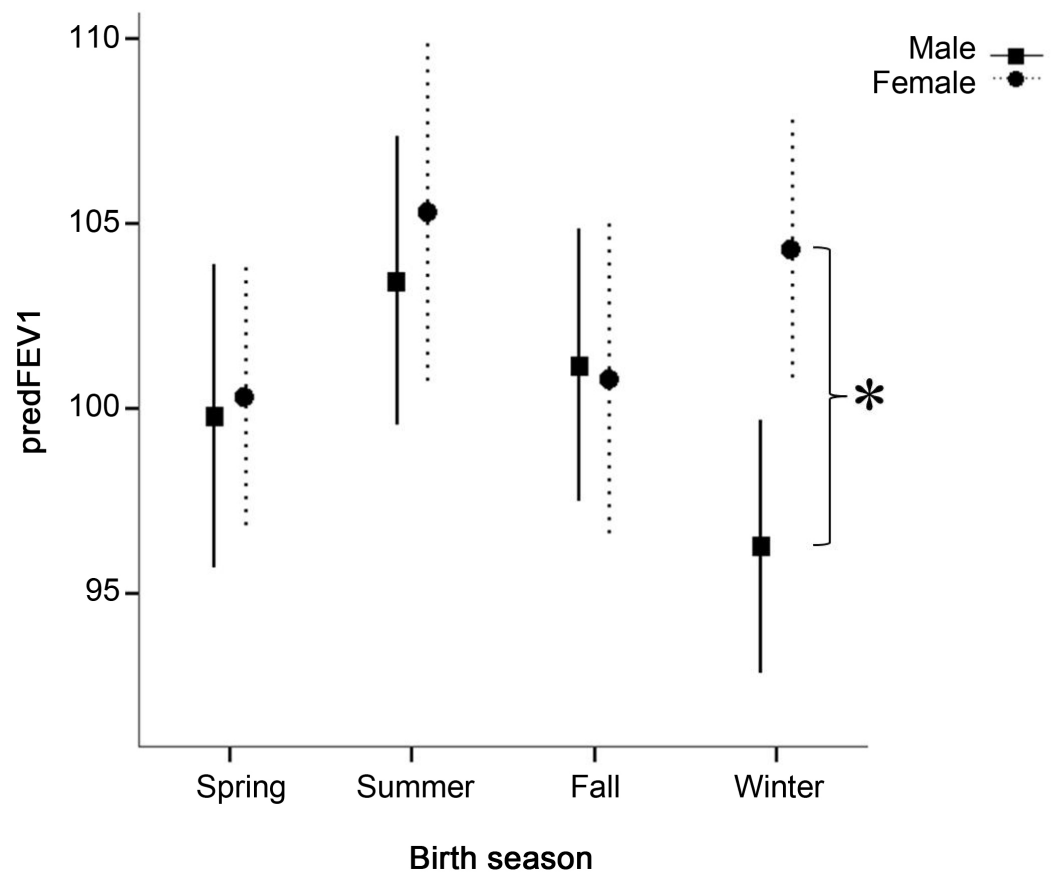

Figure 1. Comparison of lung functions between men and women according to birth seasons. ${ }^{*} \mathrm{p}<0.05$; FEV1 $\%$ predicted was lower in men born in winter than in women born in winter (December-February). 
Table 2. Comparison between birth seasons (spring, summer, and fall vs. winter).

\begin{tabular}{|c|c|c|c|c|}
\hline & & $\begin{array}{l}\text { Spring, summer, } \\
\text { and fall }\end{array}$ & Winter & $\mathrm{p}$-value \\
\hline \multirow[t]{13}{*}{ Male } & $\mathrm{N}$ & 371 & 159 & \\
\hline & Age (years) & $68.4 \pm 7.3$ & $68.5 \pm 6.3$ & 0.85 \\
\hline & Height $(\mathrm{cm})$ & $166.9 \pm 6.1$ & $166.7 \pm 5.3$ & 0.62 \\
\hline & Weight $(\mathrm{kg})$ & $65.6 \pm 9.2$ & $65.3 \pm 8.6$ & 0.73 \\
\hline & BMI $\left(\mathrm{kg} / \mathrm{m}^{2}\right)$ & $23.5 \pm 2.8$ & $23.5 \pm 2.6$ & 0.92 \\
\hline & FVC (L) & $3.64 \pm 0.70$ & $3.51 \pm 0.63$ & $<0.05$ \\
\hline & FEV1 (L) & $2.64 \pm 0.64$ & $2.50 \pm 0.61$ & $<0.05$ \\
\hline & FEV1/FVC (\%) & $72.3 \pm 10.0$ & $70.9 \pm 10.8$ & 0.15 \\
\hline & predFVC (\%) & $96.4 \pm 16.6$ & $93.7 \pm 15.6$ & 0.08 \\
\hline & predFEV1 (\%) & $101.3 \pm 22.0$ & $96.3 \pm 21.9$ & $<0.05$ \\
\hline & Smoking (PY) & $14.7 \pm 21.8$ & $13.8 \pm 18.1$ & 0.64 \\
\hline & Smoker (\%) & $45.3 \%(168 / 371)$ & $49.1 \%(78 / 159)$ & 0.43 \\
\hline & FEV1/FVC < $70(\%)$ & $32.1 \%(119 / 371)$ & $34.0 \%(54 / 159)$ & 0.67 \\
\hline \multirow[t]{13}{*}{ Female } & $\mathrm{N}$ & 361 & 117 & \\
\hline & Age (years) & $67.8 \pm 6.9$ & $67.0 \pm 8.2$ & 0.37 \\
\hline & Height $(\mathrm{cm})$ & $153.7 \pm 6.0$ & $153.5 \pm 5.8$ & 0.86 \\
\hline & Weight (kg) & $58.5 \pm 9.1$ & $58.8 \pm 9.4$ & 0.75 \\
\hline & BMI $\left(\mathrm{kg} / \mathrm{m}^{2}\right)$ & $24.8 \pm 3.6$ & $25.0 \pm 3.9$ & 0.60 \\
\hline & FVC (L) & $2.47 \pm 0.46$ & $2.51 \pm 0.44$ & 0.44 \\
\hline & FEV1 (L) & $1.95 \pm 0.40$ & $1.99 \pm 0.38$ & 0.28 \\
\hline & FEV1/FVC (\%) & $78.7 \pm 6.9$ & $79.5 \pm 6.5$ & 0.28 \\
\hline & predFVC (\%) & $93.8 \pm 17.5$ & $95.0 \pm 15.5$ & 0.51 \\
\hline & predFEV1 (\%) & $102.0 \pm 23.2$ & $104.3 \pm 20.1$ & 0.33 \\
\hline & Smoking (PY) & $0.7 \pm 4.4$ & $0.2 \pm 1.9$ & 0.10 \\
\hline & Smoker (\%) & $3.3 \%(12 / 361)$ & $2.6 \%(3 / 117)$ & 0.68 \\
\hline & FEV1/FVC < $70(\%)$ & $7.2 \%(26 / 361)$ & $7.7 \%(9 / 117)$ & 0.86 \\
\hline
\end{tabular}

Abbreviations: BMI, Body mass index; FVC, Forced vital capacity; FEV1, Forced expiratory volume in 1 second; predFVC, FVC \% predicted; predFEV1, FEV1 \% predicted; PY, pack-years; Spring, March-May; Summer, June-August; Fall, September-November; Winter, December-February.

of all men and male ever-smokers were $14.4 \pm 20.8$ and $32.7 \pm 19.6$ pack-years, respectively. However, out of the 478 women, only 15 (3.1\%) were ever-smokers; mean smoking exposure of all women and female ever-smokers were $0.6 \pm 4.0$ and $19.0 \pm 12.8$ pack-years, respectively (Table 1 ).

When the patients were divided into two groups based on birth season, among the male ever-smokers $(\mathrm{N}=246)$, lung functions (FEV1 and FEV1 \% predicted) were lower in men born in winter than in those born in other seasons (Table 5). However, among the never-smokers $($ men $=284$ and women $=463)$, lung functions were not different between the two groups based on birth season (Table 5). 
Table 3. Relationships between pulmonary function test findings and study variables (univariate analysis using linear regression models) in men $(\mathrm{N}=530)$ and women $(\mathrm{N}=$ 478).

\begin{tabular}{|c|c|c|c|c|c|c|c|}
\hline & & & FVC & FEV1 & FEV1/FVC & predFVC & predFEV 1 \\
\hline \multirow[t]{12}{*}{ Men } & Age & $r$ & -0.315 & -0.413 & -0.273 & 0.011 & -0.001 \\
\hline & & $\mathrm{p}$ & $<0.05$ & $<0.05$ & $<0.05$ & 0.80 & 0.98 \\
\hline & Height & $r$ & 0.424 & 0.347 & 0.023 & -0.051 & -0.019 \\
\hline & & $\mathrm{p}$ & $<0.05$ & $<0.05$ & 0.60 & 0.25 & 0.67 \\
\hline & Weight & $r$ & 0.233 & 0.266 & 0.152 & -0.097 & 0.007 \\
\hline & & $\mathrm{p}$ & $<0.05$ & $<0.05$ & $<0.05$ & $<0.05$ & 0.88 \\
\hline & BMI & $r$ & 0.015 & 0.102 & 0.168 & -0.085 & 0.022 \\
\hline & & $\mathrm{p}$ & 0.74 & $<0.05$ & $<0.05$ & 0.05 & 0.62 \\
\hline & Smoking & $r$ & -0.093 & -0.218 & -0.261 & -0.040 & -0.185 \\
\hline & & $\mathrm{p}$ & $<0.05$ & $<0.05$ & $<0.05$ & 0.37 & $<0.05$ \\
\hline & $\begin{array}{c}\text { Birth } \\
\text { season }\end{array}$ & $r$ & 0.090 & 0.104 & 0.063 & 0.076 & 0.105 \\
\hline & & $\mathrm{p}$ & $<0.05$ & $<0.05$ & 0.15 & 0.08 & $<0.05$ \\
\hline \multirow[t]{12}{*}{ Women } & Age & $r$ & -0.386 & -0.430 & -0.176 & 0.065 & 0.151 \\
\hline & & $\mathrm{p}$ & $<0.05$ & $<0.05$ & $<0.05$ & 0.16 & $<0.05$ \\
\hline & Height & $r$ & 0.519 & 0.494 & 0.054 & -0.147 & -0.204 \\
\hline & & $\mathrm{p}$ & $<0.05$ & $<0.05$ & 0.24 & $<0.05$ & $<0.05$ \\
\hline & Weight & $r$ & 0.160 & 0.188 & 0.106 & -0.186 & -0.139 \\
\hline & & $\mathrm{p}$ & $<0.05$ & $<0.05$ & $<0.05$ & $<0.05$ & $<0.05$ \\
\hline & BMI & $r$ & -0.103 & -0.060 & 0.086 & -0.127 & -0.047 \\
\hline & & $\mathrm{p}$ & $<0.05$ & 0.19 & 0.06 & $<0.05$ & 0.30 \\
\hline & Smoking & $r$ & -0.097 & -0.147 & -0.185 & -0.125 & -0.158 \\
\hline & & $\mathrm{p}$ & $<0.05$ & $<0.05$ & $<0.05$ & $<0.05$ & $<0.05$ \\
\hline & $\begin{array}{l}\text { Birth } \\
\text { season }\end{array}$ & $r$ & -0.035 & -0.050 & -0.050 & -0.030 & -0.044 \\
\hline & & $\mathrm{p}$ & 0.44 & 0.28 & 0.28 & 0.51 & 0.33 \\
\hline
\end{tabular}

Abbreviations: BMI, Body mass index; FVC, Forced vital capacity; FEV1, Forced expiratory volume in 1 second; predFVC, FVC \% predicted; predFEV1, FEV1 \% predicted; Smoking, pack-years; Birth season, Spring, Summer, and Fall vs. Winter. $r$. Pearson correlation coefficient.

Figure 2 shows that male smokers with $<30$ pack-years born in winter had a more rapid decline in FEV1 \% predicted than did those born in other seasons (95.2 \pm 19.7 vs. $103.8 \pm 19.5, \mathrm{p}<0.05)$. However, among both never-smokers and heavy smokers with $\geq 30$ pack-years, there were no differences in FEV1 \% predicted between the two groups based on birth season (Figure 2).

\section{Discussion}

In the present study, we found that FEV1 \% predicted was lower in men born in winter than in those born in other seasons (spring, summer, and fall), suggesting that the birth season as an early life factor somehow affects adult lung function 
Table 4. Multivariate analysis using linear regression models in men $(\mathrm{N}=530)$ and women $(\mathrm{N}=478)$.

\begin{tabular}{|c|c|c|c|c|c|c|c|}
\hline & & & FVC & FEV1 & FEV1/FVC & predFVC & predFEV 1 \\
\hline \multirow[t]{10}{*}{ Men } & Age & $\beta$ & -0.255 & -0.344 & -0.234 & 0.001 & 0.024 \\
\hline & & $\mathrm{p}$ & $<0.05$ & $<0.05$ & $<0.05$ & 0.99 & 0.60 \\
\hline & Height & $\beta$ & 0.392 & 0.256 & -0.090 & -0.011 & -0.034 \\
\hline & & $\mathrm{p}$ & $<0.05$ & $<0.05$ & 0.07 & 0.84 & 0.51 \\
\hline & Weight & $\beta$ & -0.046 & 0.031 & 0.131 & -0.116 & -0.006 \\
\hline & & $\mathrm{p}$ & 0.33 & 0.49 & $<0.05$ & $<0.05$ & 0.91 \\
\hline & Smoking & $\beta$ & -0.054 & -0.168 & -0.228 & -0.055 & -0.192 \\
\hline & & $\mathrm{p}$ & 0.17 & $<0.05$ & $<0.05$ & 0.22 & $<0.05$ \\
\hline & $\begin{array}{c}\text { Birth } \\
\text { season }\end{array}$ & $\beta$ & 0.080 & 0.094 & 0.061 & 0.076 & 0.103 \\
\hline & & $\mathrm{p}$ & $<0.05$ & $<0.05$ & 0.14 & 0.08 & $<0.05$ \\
\hline \multirow[t]{10}{*}{ Women } & Age & $\beta$ & -0.272 & -0.325 & -0.170 & 0.018 & 0.101 \\
\hline & & $\mathrm{p}$ & $<0.05$ & $<0.05$ & $<0.05$ & 0.69 & $<0.05$ \\
\hline & Height & $\beta$ & 0.476 & 0.424 & -0.017 & -0.080 & -0.146 \\
\hline & & $\mathrm{p}$ & $<0.05$ & $<0.05$ & 0.73 & 0.11 & $<0.05$ \\
\hline & Weight & $\beta$ & -0.068 & -0.030 & 0.080 & -0.157 & -0.073 \\
\hline & & $\mathrm{p}$ & 0.09 & 0.45 & 0.10 & $<0.05$ & 0.13 \\
\hline & Smoking & $\beta$ & -0.111 & -0.160 & -0.184 & -0.127 & -0.154 \\
\hline & & $\mathrm{p}$ & $<0.05$ & $<0.05$ & $<0.05$ & $<0.05$ & $<0.05$ \\
\hline & $\begin{array}{c}\text { Birth } \\
\text { season }\end{array}$ & $\beta$ & -0.022 & -0.031 & -0.031 & -0.026 & -0.041 \\
\hline & & $\mathrm{p}$ & 0.55 & 0.40 & 0.48 & 0.56 & 0.36 \\
\hline
\end{tabular}

Abbreviations: BMI, Body mass index; FVC, Forced vital capacity; FEV1, Forced expiratory volume in 1 second; predFVC, FVC \% predicted; predFEV1, FEV1 \% predicted; Smoking, pack-years; Birth season, Spring, Summer, and Fall vs. Winter. $\beta$ : Standardized coefficient beta.

depending on an individual's sex. Our finding also agrees with those of the two recent European multi-center cohort studies, which showed an association between lung function decline and birth season [9].

Early childhood is a critical time window for subsequent lung health. Adverse childhood environmental exposures can restrain growth [12], modulate lung function [12] [13], and induce changes in gene expression, thereby modulating airway pathophysiology [14] [15]. Various pathways leading from early life factors to adult respiratory health outcomes in later life have been relatively well studied, including fetal and early infant growth patterns, preterm birth, maternal obesity, diet and smoking, children's diet, allergen exposure and respiratory tract infections, and genetic susceptibility [16]. However, the potential impact of early life factors on lung function decline has been scarcely studied. Nevertheless, data from two recent European cohort studies (SAPALDIA and ECRHS) showed early life factors could predict lung function decline in old age [9]. Taken together, the data from these studies revealed that the season of birth, higher maternal age at delivery, maternal smoking, and the presence of younger siblings 
Table 5. Comparison between birth seasons according to smoking history (male never-smokers, $\mathrm{N}=284$; female never-smokers, $\mathrm{N}=463$; male ever-smokers, $\mathrm{N}=246$ ).

\begin{tabular}{|c|c|c|c|c|c|}
\hline & & & $\begin{array}{l}\text { Spring, } \\
\text { summer, } \\
\text { and fall }\end{array}$ & Winter & $\mathrm{p}$-value \\
\hline \multirow[t]{22}{*}{ Never-smoker } & Male & $\mathrm{N}$ & 203 & 81 & \\
\hline & $(\mathrm{N}=284)$ & Age (years) & $68.2 \pm 7.4$ & $68.4 \pm 5.7$ & 0.79 \\
\hline & & Height (cm) & $167.0 \pm 6.0$ & $167.0 \pm 5.4$ & 0.98 \\
\hline & & Weight (kg) & $66.5 \pm 9.4$ & $66.7 \pm 8.6$ & 0.87 \\
\hline & & BMI $\left(\mathrm{kg} / \mathrm{m}^{2}\right)$ & $23.8 \pm 2.7$ & $23.9 \pm 2.5$ & 0.84 \\
\hline & & FVC (L) & $3.65 \pm 0.70$ & $3.52 \pm 0.59$ & 0.16 \\
\hline & & FEV1 (L) & $2.70 \pm 0.62$ & $2.60 \pm 0.58$ & 0.21 \\
\hline & & FEV1/FVC (\%) & $74.0 \pm 9.2$ & $73.5 \pm 9.1$ & 0.64 \\
\hline & & predFVC (\%) & $96.2 \pm 16.9$ & $93.6 \pm 14.2$ & 0.22 \\
\hline & & predFEV1 (\%) & $103.5 \pm 22.1$ & $100.3 \pm 21.0$ & 0.27 \\
\hline & & $\begin{array}{c}\text { FEV } 1 / \text { FVC }<70 \\
(\%)\end{array}$ & $\begin{array}{c}24.6 \% \\
(50 / 203)\end{array}$ & $\begin{array}{l}24.7 \% \\
(20 / 81)\end{array}$ & 0.99 \\
\hline & Female & $\mathrm{N}$ & 349 & 114 & \\
\hline & $(\mathrm{N}=463)$ & Age (years) & $67.9 \pm 6.8$ & $67.0 \pm 8.2$ & 0.28 \\
\hline & & Height (cm) & $153.5 \pm 5.9$ & $153.5 \pm 5.8$ & 0.10 \\
\hline & & Weight (kg) & $58.5 \pm 9.1$ & $58.9 \pm 9.5$ & 0.72 \\
\hline & & BMI $\left(\mathrm{kg} / \mathrm{m}^{2}\right)$ & $24.8 \pm 3.5$ & $25.0 \pm 3.9$ & 0.63 \\
\hline & & FVC (L) & $2.47 \pm 0.46$ & $2.50 \pm 0.44$ & 0.56 \\
\hline & & FEV1 (L) & $1.96 \pm 0.39$ & $1.99 \pm 0.38$ & 0.43 \\
\hline & & FEV1/FVC (\%) & $79.0 \pm 6.7$ & $79.5 \pm 6.5$ & 0.46 \\
\hline & & predFVC (\%) & $94.2 \pm 17.5$ & $94.8 \pm 15.7$ & 0.74 \\
\hline & & predFEV1 (\%) & $102.8 \pm 22.9$ & $104.2 \pm 20.3$ & 0.57 \\
\hline & & $\begin{array}{c}\mathrm{FEV} 1 / \mathrm{FVC}<70 \\
(\%)\end{array}$ & $6.6 \%(23 / 349)$ & $\begin{array}{c}7.9 \% \\
(9 / 114)\end{array}$ & 0.63 \\
\hline \multirow[t]{12}{*}{ Ever-smoker } & Male & $\mathrm{N}$ & 168 & 78 & \\
\hline & $(\mathrm{N}=246)$ & Age (years) & $68.6 \pm 7.1$ & $68.6 \pm 7.0$ & 1.00 \\
\hline & & Height $(\mathrm{cm})$ & $166.9 \pm 6.2$ & $166.3 \pm 5.3$ & 0.48 \\
\hline & & Weight (kg) & $64.6 \pm 8.8$ & $63.9 \pm 8.4$ & 0.58 \\
\hline & & BMI $\left(\mathrm{kg} / \mathrm{m}^{2}\right)$ & $23.2 \pm 2.7$ & $23.1 \pm 2.6$ & 0.84 \\
\hline & & FVC (L) & $3.64 \pm 0.71$ & $3.50 \pm 0.67$ & 0.14 \\
\hline & & FEV1 (L) & $2.57 \pm 0.65$ & $2.39 \pm 0.62$ & $<0.05$ \\
\hline & & FEV1/FVC (\%) & $70.3 \pm 10.5$ & $68.3 \pm 11.9$ & 0.18 \\
\hline & & predFVC (\%) & $96.6 \pm 16.2$ & $93.8 \pm 17.1$ & 0.21 \\
\hline & & predFEV1 (\%) & $98.7 \pm 21.6$ & $92.1 \pm 22.2$ & $<0.05$ \\
\hline & & Smoking (PY) & $34.2 \pm 21.1$ & $29.5 \pm 15.5$ & 0.09 \\
\hline & & $\begin{array}{c}\text { FEV1/FVC }<70 \\
(\%)\end{array}$ & $\begin{array}{c}41.1 \% \\
(69 / 168)\end{array}$ & $\begin{array}{c}43.6 \% \\
(34 / 78)\end{array}$ & 0.71 \\
\hline
\end{tabular}

Abbreviations: BMI, Body mass index; FVC, Forced vital capacity; FEV1, Forced expiratory volume in 1 second; predFVC, FVC \% predicted; predFEV1, FEV1 \% predicted; PY, pack-years; Spring, March-May; Summer, June-August; Fall, September-November; Winter, December-February. 


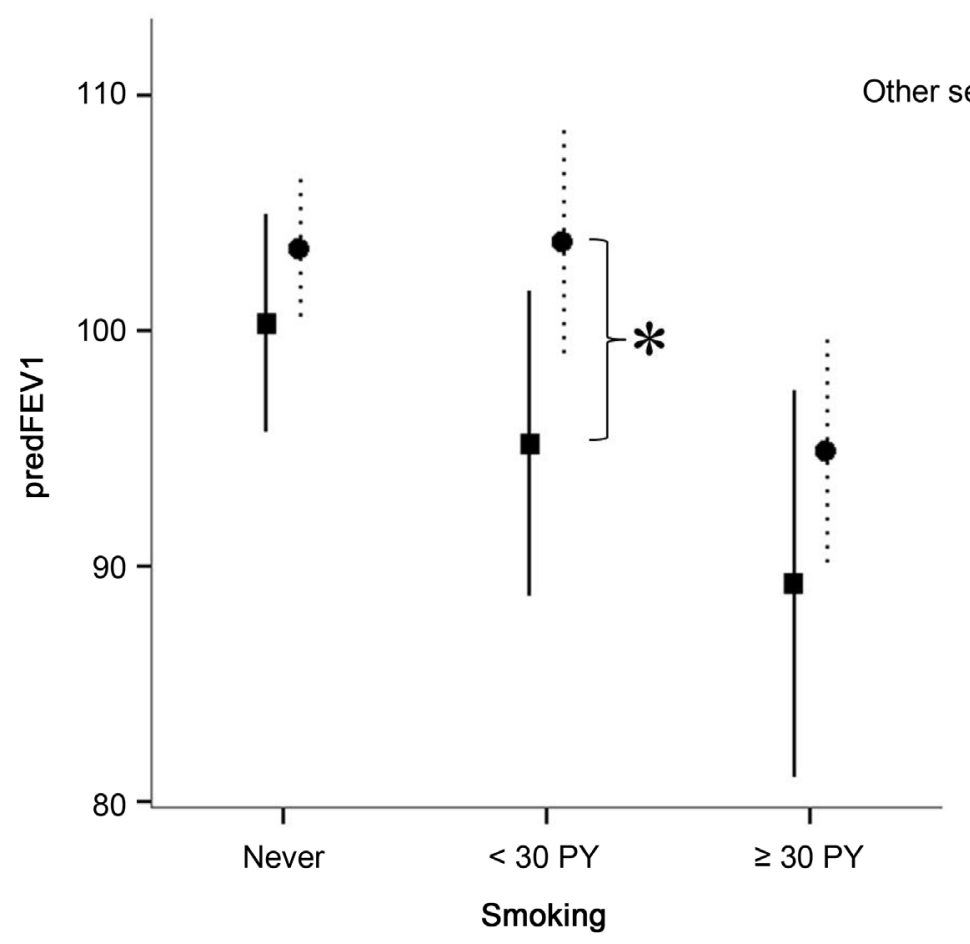

Winter ther seasons

Figure 2. Comparison of lung functions between birth seasons in men according to smoking history (never-smoker vs. ever-smoker with $<30$ pack-years vs. heavy smoker with $\geq 30$ pack-years). ${ }^{*} \mathrm{p}<0.05$; FEV1 $\%$ predicted showed a more rapid decline in male smokers with $<30$ pack-years born in winter (December-February) than in those born in other seasons.

were associated with more rapid lung function decline, whereas early day-care attendance, the presence of older siblings, and childhood pet keeping appeared to be associated with a less rapid decline. Moreover, similar to our patients, the participants in those studies who were born in the winter months had a more rapid decline in lung function than did those born in the other months. Being born in winter has been related to in utero exposures to viral infections or allergens and to a higher frequency of respiratory infections in the first months of life, both of which probably are major influences on the subsequent establishment of immune response [17] [18]. In particular, in utero and early life vitamin D deficiency, which is more frequent in winter, could be associated with the increased risk of recurrent wheezing illness and the diagnosis of asthma in childhood [19]. This observation may be attributable to the fact that vitamin D modifies the risk for viral infection, as shown by birth cohort studies that have correlated maternal vitamin D intake or cord blood 25-hydroxyvitamin D (25[OH]D) levels with early childhood respiratory infections and wheezing. This finding might also suggest a potential pathway for reducing asthma risk. However, some uncertainty still remains in this area of research, because Camargo et al. reported no association between cord blood 25(OH)D levels and incident asthma at 5 years in a New Zealand cohort of 922 infants.

The sex of an individual plays a major role in both the healthy and diseased lung from very early life onwards. Sex hormones exert regulatory effects on lung 
development, physiology, and pathology [20]. Sex also affects airway inflammation and the prevalence and severity of many major lung diseases, including pulmonary fibrosis, asthma, and lung cancer. Data from both human and animal studies indicate that sex hormones might contribute to disease pathogenesis or serve as protective factors, depending on the disease involved [21]. Traditionally, COPD has been regarded a male-specific disease owing to the difference in the prevalence of smokers between the sexes [22]. Although there is controversy about the association between sex and the incidence of COPD according to country [23] [24], male sex was found to be an independent risk factor for COPD after adjustment for smoking in Korea (prevalence of COPD among nonsmokers: male $14.6 \%$ vs. female $7.6 \%$ ) [25]. Furthermore, accumulating evidence suggests that sex has an impact on the incidence and severity of and susceptibility to COPD. Many studies have assessed the role of sex hormones in the pathogenesis of COPD. It is now known that the human airway smooth muscle is actively involved in the inflammatory process crucial for COPD pathogenesis. Androgens appear to be detrimental in the pathogenesis of lipopolysaccharide-induced airway inflammation and hyperresponsiveness [26]. In contrast, estrogen suppresses lung inflammatory responses through its effects on vascular cell adhesion molecules and proinflammatory cytokines [27]. In other words, male sex hormones promote lung inflammatory responses while female sex hormones ameliorate these processes [26] [27]. Consistent with the findings of these studies, we also found a stronger overall impact of birth season in men than in women, even after adjustment for pack-years among smokers. Several known mechanisms may explain the sex-related differences in susceptibility to lifetime exposures, [28] [29] [30] and several studies have shown a higher respiratory vulnerability in men than in women. Another interesting observation was that the deficit in lung function associated with the winter season appeared to be larger in male smokers.

Smoking is known as the main risk factor for accelerated lung function decline in adults; however, the mechanisms underlying the variations in susceptibility to tobacco exposure between individuals are not well understood. In our study, lung function decline was more pronounced in male smokers who were born during winter than in those born during other seasons. This indicates that susceptibility to lung insults in later adulthood might be programmed early in life. When the patients were divided into two groups based on birth season (winter vs. spring, summer, and fall), among male ever-smokers $(\mathrm{N}=246)$, lung functions (FEV1 and FEV1 \% predicted) were lower in men born in winter than in those born in other seasons (spring, summer, and fall). This means that if a man born in winter smoke, he will have lower lung function than those born in other seasons. However, among male and female never-smokers, lung functions were not different between the two groups based on birth season. A synergistic effect of parental smoking has been described by Guerra et al. [31] who found a steeper decline of lung function in young adults exposed to both parental and individual smoking. Previous findings on synergistic effects support our novel 
finding about an increased susceptibility to smoking in subjects born during the winter season. In case of female smokers, we could not find a correlation between smoking and birth season because of their small number in the study population. Moreover, we did not observe a significant effect of birth season on lung function in heavy smokers with more than 30 pack-years. These findings suggest that heavy smoking is the most powerful risk factor for accelerated lung function decline.

Investigating early life factors and their potential interactions requires large study populations; however, we enrolled patients from a very specific demographic group, thus limiting the generalizability of our observations to other populations. Therefore, we investigated only birth season, sex, and smoking exposure and did not investigate other early life factors such as fetal and early infant growth patterns, preterm birth, maternal obesity, diet and smoking, children's diet, allergen exposure and respiratory tract infections, and genetic susceptibility. Another limitation of our study was the use of pre-bronchodilator spirometric values for evaluating lung function. Because of the lack of post-bronchodilator measurements, we could not rule out some cases of transient airflow obstruction. Another limitation, as we discussed above, was the relatively small number of female smokers in our study group, which made it difficult to evaluate the correlation between birth season and smoking in women.

\section{Conclusion}

Our study demonstrated that unlike female patients, male patients born during winter had lower lung function than did those born in other seasons. These results suggest that birth season might be a predictor of lung function as an early life factor. Furthermore, birth season has different effects on adult lung function depending on the patient's sex.

\section{Conflict of Interest}

There are no conflicts of interest among the authors.

\section{References}

[1] Murray, C.J., Lopez, A.D., Black, R., Mathers, C.D., Shibuya, K., Ezzati, M., Salomon, J.A., Michaud, C.M., Walker, N. and Vos, T. (2007) Global Burden of Disease 2005: Call for Collaborators. Lancet, 370, 109-110. https://doi.org/10.1016/S0140-6736(07)61064-2

[2] Salvi, S.S. and Barnes, P.J. (2009) Chronic Obstructive Pulmonary Disease in NonSmokers. Lancet, 374, 733-743. https://doi.org/10.1016/S0140-6736(09)61303-9

[3] Fletcher, C. and Peto, R. (1977) The Natural History of Chronic Airflow Obstruction. British Medical Journal, 1, 1645-1648. https://doi.org/10.1136/bmj.1.6077.1645

[4] Mannino, D.M., Watt, G., Hole, D., Gillis, C., Hart, C., McConnachie, A., Davey Smith, G., Upton, M., Hawthorne, V., Sin, D.D., Man, S.F., Van Eeden, S., Mapel, D.W. and Vestbo, J. (2006) The Natural History of Chronic Obstructive Pulmonary Disease. European Respiratory Journal, 27, 627-643.

https://doi.org/10.1183/09031936.06.00024605 
[5] Shi, W., Bellusci, S. and Warburton, D. (2007) Lung Development and Adult Lung Diseases. Chest, 132, 651-656. https://doi.org/10.1378/chest.06-2663

[6] Weiss, S.T. and Ware, J.H. (1996) Overview of Issues in the Longitudinal Analysis of Respiratory Data. American Journal of Respiratory and Critical Care Medicine, 154, S208-211. https://doi.org/10.1164/ajrccm/154.6_Pt_2.S208

[7] Stocks, J. and Sonnappa, S. (2013) Early Life Influences on the Development of Chronic Obstructive Pulmonary Disease. Therapeutic Advances in Respiratory Disease, 7, 161-173. https://doi.org/10.1177/1753465813479428

[8] Carraro, S., Scheltema, N., Bont, L. and Baraldi, E. (2014) Early-Life Origins of Chronic Respiratory Diseases: Understanding and Promoting Healthy Ageing. European Respiratory Journal, 44, 1682-1696. https://doi.org/10.1183/09031936.00084114

[9] Dratva, J., Zemp, E., Dharmage, S.C., Accordini, S., Burdet, L., Gislason, T., Heinrich, J., Janson, C., Jarvis, D., de Marco, R., Norbäck, D., Pons, M., Real, F.G., Sunyer, J., Villani, S., Probst-Hensch, N. and Svanes, C. (2016) Early Life Origins of Lung Ageing: Early Life Exposures and Lung Function Decline in Adulthood in Two European Cohorts Aged 28 - 73 Years. PLoS ONE, 11, e0145127.

https://doi.org/10.1371/journal.pone.0145127

[10] Miller, M.R., Hankinson, J., Brusasco, V., Burgos, F., Casaburi, R., Coates, A., Crapo, R., Enright, P., van der Grinten, C.P., Gustafsson, P., Jensen, R., Johnson, D.C., MacIntyre, N., McKay, R., Navajas, D., Pedersen, O.F., Pellegrino, R., Viegi, G. and Wanger, J., ATS/ERS Task Force (2005) Standardisation of Spirometry. European Respiratory Journal, 26, 319-338. https://doi.org/10.1183/09031936.05.00034805

[11] Vestbo, J., Hurd, S.S., Agustí, A.G., Jones, P.W., Vogelmeier, C., Anzueto, A., Barnes, P.J., Fabbri, L.M., Martinez, F.J., Nishimura, M., Stockley, R.A., Sin, D.D. and Rodriguez-Roisin, R. (2013) Global Strategy for the Diagnosis, Management, and Prevention of Chronic Obstructive Pulmonary Disease: GOLD Executive Summary. American Journal of Respiratory and Critical Care Medicine, 187, 347365. https://doi.org/10.1164/rccm.201204-0596PP

[12] Apostol, G.G., Jacobs, D.R.J., Tsai, A.W., Crow, R.S., Williams, O.D., Townsend, M.C. and Beckett, W.S.(2002) Early Life Factors Contribute to the Decrease in Lung Function between Ages 18 and 40: The Coronary Artery Risk Development in Young Adults Study. American Journal of Respiratory and Critical Care Medicine, 166, 166-172. https://doi.org/10.1164/rccm.2007035

[13] Barker, D.J., Godfrey, K.M., Fall, C., Osmond, C., Winter, P.D. and Shaheen, S.O. (1991) Relation of Birth Weight and Childhood Respiratory Infection to Adult Lung Function and Death from Chronic Obstructive Airways Disease. BMJ, 303, 671-675. https://doi.org/10.1136/bmj.303.6804.671

[14] London, S.J., James, G.W., Avol, E, Rappaport, E.B. and Peters, J.M. (2001) Family History and the Risk of Early-Onset Persistent, Early-Onset Transient, and Late-Onset Asthma. Epidemiology, 12, 577-583. https://doi.org/10.1097/00001648-200109000-00019

[15] Martinez, F.D. (2009) The Origins of Asthma and Chronic Obstructive Pulmonary Disease in Early Life. Proceedings of the American Thoracic Society, 6, 272-277. https://doi.org/10.1513/pats.200808-092RM

[16] Duijts, L., Reiss, I.K., Brusselle, G. and de Jongste, J.C. (2014) Early Origins of Chronic Obstructive Lung Diseases across the Life Course. European Journal of Epidemiology, 29, 871-885. https://doi.org/10.1007/s10654-014-9981-5

[17] Gazala, E., Ron-Feldman, V., Alterman, M., Kama, S. and Novack, L. (2006) The Association between Birth Season and Future Development of Childhood Asthma. 
Pediatric Pulmonology, 41, 1125-1128. https://doi.org/10.1002/ppul.20442

[18] Gold, D.R., Bloomberg, G.R., Cruikshank, W.W., Visness, C.M., Schwarz, J., Kattan, M., O’Connor, G.T., Wood, R.A., Burger, M.S., Wright, R.J., Witter, F., Lee-Parritz, A., Sperling, R., Sadovsky, Y., Togias, A. and Gern, J.E. (2009) Parental Characteristics, Somatic Fetal Growth, and Season of Birth Influence Innate and Adaptive Cord Blood Cytokine Responses. Journal of Allergy and Clinical Immunology, 124, 10781087. https://doi.org/10.1016/j.jaci.2009.08.021

[19] Ginde, A.A. and Sutherland, E.R. (2010) Vitamin D in Asthma: Panacea or True Promise? Journal of Allergy and Clinical Immunology, 126, 59-60. https://doi.org/10.1016/j.jaci.2010.05.030

[20] Seaborn, T., Simard, M., Provost, P.R., Piedboeuf, B. and Tremblay, Y. (2010) Sex Hormone Metabolism in Lung Development and Maturation. Trends in Endocrinology \& Metabolism, 21, 729-738. https://doi.org/10.1016/j.tem.2010.09.001

[21] Carey, M.A., Card, J.W., Voltz, J.W., Arbes, S.J.J., Germolec, D.R., Korach, K.S. and Zeldin, D.C. (2007) It's All about Sex: Gender, Lung Development and Lung Disease. Trends in Endocrinology \& Metabolism, 18, 308-313.

https://doi.org/10.1016/j.tem.2007.08.003

[22] Siafakas, N.M., Vermeire, P., Pride, N.B., Paoletti, P., Gibson, J., Howard, P., Yernault, J.C., Decramer, M., Higenbottam, T. and Postma, D.S. (1995) Optimal Assessment and Management of Chronic Obstructive Pulmonary Disease (COPD). The European Respiratory Society Task Force. European Respiratory Journal, 8, 1398-1420. https://doi.org/10.1183/09031936.95.08081398

[23] Bridevaux, P.O., Probst-Hensch, N.M., Schindler, C., Curjuric, I., Felber, D.D., Braendli, O., Brutsche, M., Burdet, L., Frey, M., Gerbase, M.W., AckermannLiebrich, U., Pons, M., Tschopp, J.M., Rochat, T. and Russi, E.W. (2010) Prevalence of Airflow Obstruction in Smokers and Never-Smokers in Switzerland. European Respiratory Journal, 36, 1259-1269. https://doi.org/10.1183/09031936.00004110

[24] Hagstad, S., Ekerljung, L., Lindberg, A., Backman, H., Rönmark, E. and Lundbäck, B. (2012) COPD among Non-Smokers-Report from the Obstructive Lung Disease in Northern Sweden (OLIN) Studies. Respiratory Medicine, 106, 980-988. https://doi.org/10.1016/j.rmed.2012.03.010

[25] Kim, D.S., Kim, Y.S., Jung, K.S., Chang, J.H., Lim, C.M., Lee, J.H., Uh, S.T., Shim, J.J. and Lew, W.J. (2005) Prevalence of Chronic Obstructive Pulmonary Disease in Korea. American Journal of Respiratory and Critical Care Medicine, 172, 842-847. https://doi.org/10.1164/rccm.200502-259OC

[26] Card, J.W., Carey, M.A., Bradbury, J.A., DeGraff, L.M., Morgan, D.L., Moorman, M.P., Flake, G.P. and Zeldin, D.C. (2006) Gender Differences in Murine Airway Responsiveness and Lipopolysaccharide-Induced Inflammation. The Journal of Immunology, 177, 621-630. https://doi.org/10.4049/jimmunol.177.1.621

[27] Speyer, C.L., Rancilio, N.J., McClintock, S.D., Crawford, J.D., Gao, H, Sarma, J.V. and Ward, P.A. (2005) Regulatory Effects of Estrogen on Acute Lung Inflammation in Mice. American Journal of Physiology-Cell Physiology, 288, C881-C890. https://doi.org/10.1152/ajpcell.00467.2004

[28] Svanes, C., Sunyer, J., Plana, E., Dharmage, S., Heinrich, J., Jarvis, D., de Marco, R., Norbäck, D., Raherison, C., Villani, S., Wjst, M., Svanes, K. and Antó, J.M. (2010) Early Life Origins of Chronic Obstructive Pulmonary Disease. Thorax, 65, 14-20. https://doi.org/10.1136/thx.2008.112136

[29] Stein, R.T., Sherrill, D., Morgan, W.J., Holberg, C.J., Halonen, M., Taussig, L.M., Wright, A.L. and Martinez, F.D. (1999) Respiratory Syncitial Virus in Early Life and Risk of Wheeze and Allergy by Age 13 Years. The Lancet, 354, 541-545. 
https://doi.org/10.1016/S0140-6736(98)10321-5

[30] Openshaw, P.J., Yamaguchi, Y. and Tregoning, J.S. (2004) Childhood Infections, the Developing Immune System, and the Origins of Asthma. Journal of Allergy and Clinical Immunology, 114, 1275-1277. https://doi.org/10.1016/j.jaci.2004.08.024

[31] Palmer, D.J., Huang, R.C., Craig, J.M. and Prescott, S.L. (2014) Nutritional Influences on Epigenetic Programming: Asthma, Allergy, and Obesity. Immunology and Allergy Clinics of North America, 34, 825-837.

https://doi.org/10.1016/j.iac.2014.07.003

Submit or recommend next manuscript to SCIRP and we will provide best service for you:

Accepting pre-submission inquiries through Email, Facebook, LinkedIn, Twitter, etc. A wide selection of journals (inclusive of 9 subjects, more than 200 journals)

Providing 24-hour high-quality service

User-friendly online submission system

Fair and swift peer-review system

Efficient typesetting and proofreading procedure

Display of the result of downloads and visits, as well as the number of cited articles Maximum dissemination of your research work

Submit your manuscript at: http://papersubmission.scirp.org/

Or contact health@scirp.org 